\title{
The Determination of Some Organic Pollutants in the Waters of the Seman Basin
}

\author{
Valbona HOXHA ${ }^{1}$, Albana JANO ${ }^{1}$, Kozeta VASO ${ }^{2}$, Aurel NURO ${ }^{2}$, Enkela PORO ${ }^{1}$ \\ ${ }^{1}$ Faculty of Mathematical Engineering and Physical Engineering, \\ Polytechnic University of Tirana \\ v.hoxha@fimif.edu.al, a.jano@fimif.edu.al \\ ${ }^{2}$ Faculty of Natural Sciences, University of Tirana \\ Bulevardi "Zogu I" Tirana Albania kozeta.vaso@fshn.edu.al
}

\begin{abstract}
This article presents the results of the analysis of some organic pollutants in the surface waters of the Seman River. The organic pollutants studied were polychlorinated biphenyls (PCB), polyaromantic hydrocarbons (PAH), and chloro-organic pesticides (OPC). These pollutants were determined in 6 stations taken into study during two expeditions in April 2019 and May 2019.

For the determination of $\mathrm{PAH}$, the extraction was performed with the liquid-liquid method in the presence of hexane as the extracting solvent and the chemical analyzes were performed by the gas chromatography technique using a flame ionization detector (GC/FID).

For the determination of chloro-organic pesticides and PCB, the extraction was performed by the liquid-liquid method using hexane as the extraction solvent.

The determination of organochlorine pesticides was based on the EPA 8081 standard using the external standard method, by a gas chromatography technique and electron capture detector (GC/ECD).

The determination of PCBs was based on the standard with 7 markers, donated by IAEA/MEL, Monaco, Monte-Carlo, using the method with an external standard in the gas chromatography technique with an electron capture detector (GC/ECD).

The presence of all organic pollutants was identified in all samples studied. The concentration values of these pollutants, with the exception of those of station M2 and M6, do not exceed allowed EU norms.

Therefore, we say that the studied waters, except the waters of the M2 station (river channel Hoxhara) and M6 (Mbrostar the bridge at the entrance of Fier) belong to good environmental quality.
\end{abstract}

Keywords: Seman basin, PCB, PAH, OPC, GC, ECD, FID.

\section{Introduction}

Semani is one of the main rivers of the hydrographic territory of Albania. The catchment area of this river is located in Central Albania. With the main flow direction from east to west, Semani is formed by the confluence of the Devoll River and the Osum River. Its total catchment area is $5949 \mathrm{~km}^{2}$, with a length of $281 \mathrm{~km}$, an average annual flow which reaches $96 \mathrm{~m}^{3} / \mathrm{sec}$ and a location at $863 \mathrm{~m}$ above sea level. [5] From previous studies it has been noticed that the month with the lowest temperature in the hydrographic network of the Seman River is January with a temperature of $2{ }^{\circ} \mathrm{C}-7.6^{\circ} \mathrm{C}$ while the month with the highest temperature is August with a temperature of $16{ }^{\circ} \mathrm{C}-25^{\circ} \mathrm{C}$. In terms of seasonal distribution, the lowest water temperatures in the Seman hydrographic network are observed in winter $\left(3{ }^{\circ} \mathrm{C}-7.4^{\circ} \mathrm{C}\right)$ and spring $\left(7.3^{\circ} \mathrm{C}-14.5^{\circ} \mathrm{C}\right)$, while the highest temperatures in autumn $\left(9.8^{\circ} \mathrm{C}-16.7^{\circ} \mathrm{C}\right)$ and summer $\left(14.7 . \mathrm{C}-24.5^{\circ} \mathrm{C}\right) .[5]$ The Devoll River feeds the Seman River with about $88 \%$ of its waters. Due to the basic geological characteristics of the basin (e.g. limestone, karst) during river flow, the Seman River has a relatively high content of mineral components. Water mineralization occurs inversely related to the total volume of water flow and varies during different months of the year, almost synchronously with the monthly distribution of water inflows itself. The average mineralization of the waters of the Devoll River is $334 \mathrm{mg} / 1$, while that of the Osum River is $345 \mathrm{mg} / 1$. Based on the classification of natural waters, the waters of these two rivers are included in the category of waters with medium mineralization. After the confluence of the 
waters of Osum with those of Devoll and up to the discharge of the waters of Seman in the Adriatic Sea, the mineralization increases having an average value higher than $370 \mathrm{mg} / 1$.

Chloro-organic pesticides PCBs and PAHs are organic pollutants prevalent in many ecosystems worldwide Pesticides are substances used to prevent, destroy, inhibit or tame any pests ranging from insects, animals, fungi, bacteria and viruses. Pesticides are grouped into three main classes: insecticides, herbicides and fungicides, which are characterized by very different physico-chemical properties, important differences in polarity, volatility and environmental stability.[10]

In Albania, organic chlorine pesticides were used in significant quantities before the 90s. Their usage has been primarily as insecticides. The most common have been DDT, Lindane and HCB (Hexachlor Benzene). Most are imported from other countries, however lindane is produced in Albania, in the industrial area of Porto-Romano, an area where the environmental impact of this pesticide is still felt.

PCB-s are organic compounds, which are obtained by the chlorination of biphenyl in the presence of a suitable catalyst. The presence of PCBs in Albania is especially related to their atmospheric deposits, because their uses are very low, mainly as oils of electric transformers after the 90s (Koci, 2000). The same properties which make PCBs interesting for industrial use cause adverse effects on reproduction, development, and endocrine function [4]; [9]

Polycyclic aromatic hydrocarbons (PAHs) include a large group of organic compounds characterized by at least two benzene rings joined together.

PAHs can be found almost everywhere, in the air, on land, water from a natural or an anthropogenic source. Natural sources that release PAHs into the environment are volcanoes, forest fires and biosynthesis from plants and microorganisms. Anthropogenic sources of PAHs can be classified into two categories: stationary sources and mobile (diffuse) sources. In mobile sources, the main contribution comes from the fuel of vehicle engines, as well as from diesel engines. While in stationary sources, the main contribution belongs to combustion processes including industrial activities. [2]

Human exposure to organic pollutants can cause serious health effects such as congenital defects, damage to the immune and respiratory systems, dysfunction of the hormonal and reproductive systems, sexual disorders and shortening of lactation in women, increased risk of some cancers and even lowering the level of intelligence. [6]; [8]; [11]

\section{Materials and Methods}

\section{- $\quad$ Sampling and Transportation of Water Samples}

Water sampling was carried out with the help of teflon containers at different points of the Seman River. The sampling method is based on [7]. For analysis, water samples were taken at 6 stations during two expeditions in April 2019 and May 2019. Water samples were transported at $+4^{\circ} \mathrm{C}$. The water sampling stations are shown in the map below. (figure 1) 


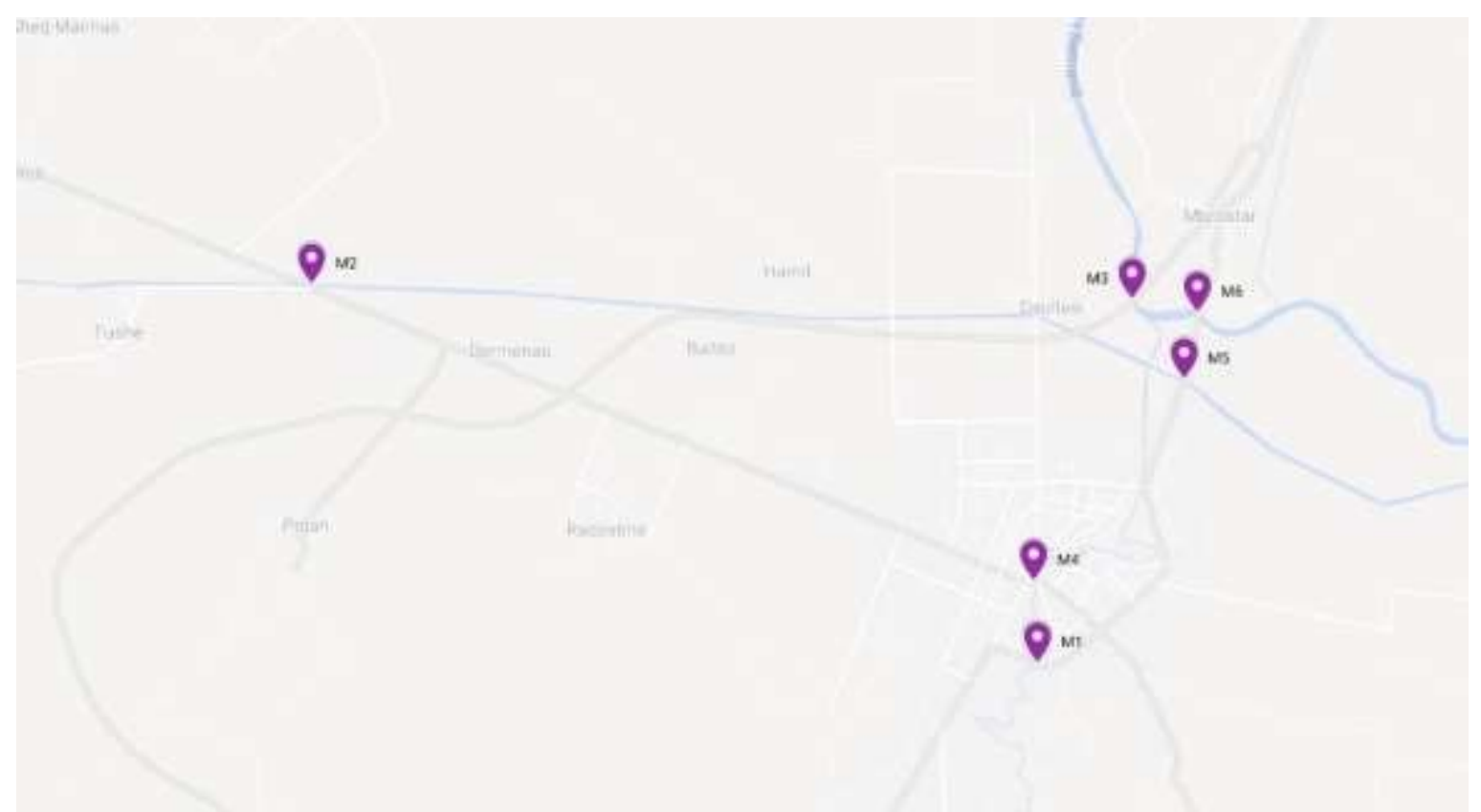

Fig 1. Water sampling stations

\section{- GC/ECD Method for Chloro-Organic Pesticides Determination}

Chlorinated pesticides in water samples were extracted using liquid-liquid extraction assisted with Hexane solvent. 1 L of water and $20 \mathrm{ml}$ Hexane as an extraction solvent was added in a separatory funnel. After shaking, the organic phase was collected in a beaker where $5 \mathrm{~g}$ of anhydrous $\mathrm{Na}_{2} \mathrm{SO}_{4}$ was added for removing water. After their concentration in $1 \mathrm{ml}$ Hexane, the samples were injected directly to GC/ECD for the stimulation of chlorinated pesticides. Separation of chloroorganic pesticides was performed in the column Rtx-5 with dimensions $30 \mathrm{~m} \times 0.25 \mathrm{~mm} \times 0.25 \mu \mathrm{m}$. The determination of organic chloride pesticides was based on the EPA 8081 standard using the external standard method in the GC/ECD apparatus.

\section{- GC/ECD Method for PCB Marker Determination}

Gas chromatographic analyses were conducted with a Varian $450 \mathrm{GC}$ instrument equipped with two PTV injectors and an ECD detector and with a 63Ni electron-capture detector. The column used for the isolation of PCBs (simultaneously) was a Rtx $-5(30 \mathrm{~m} \times 0.33 \mathrm{~mm} \times 0.2 \mu \mathrm{m})$ capillary column. The injector and detector temperatures were set at $280^{\circ} \mathrm{C}$ and $300^{\circ} \mathrm{C}$, respectively. Carrier gas was He at $1 \mathrm{ml} / \mathrm{min}$ and make-up gas was nitrogen $25 \mathrm{ml} / \mathrm{min}$. The initial oven temperature was kept at $70^{\circ} \mathrm{C}$ for $1 \mathrm{~min}$, which was increased to $200^{\circ} \mathrm{C}$ with $7^{\circ} \mathrm{C} / \mathrm{min}$, held for $7 \mathrm{~min}$, and then increased to $280^{\circ} \mathrm{C}$ with $4^{\circ} \mathrm{C} / \mathrm{min}$ for $20 \mathrm{~min}$. The temperature was finally increased to $300^{\circ} \mathrm{C}$, at $10^{\circ} \mathrm{C} / \mathrm{min}$, for $7 \mathrm{~min}$. Injection volume was $1 \mu 1$, when splitless injections were made. [1]

Calibration curves for 19 organochlorine pesticides and 7 marking PCBs were constructed with six calibration points using solutions with concentrations of $5 \mathrm{ng} / \mathrm{ml}, 10 \mathrm{ng} / \mathrm{ml}, 25 \mathrm{ng} / \mathrm{ml}, 50 \mathrm{ng} / \mathrm{ml}, 100 \mathrm{ng} / \mathrm{mL}$ and $250 \mathrm{ng} / \mathrm{mL}$. To evaluate the working method, a set of bi-distilled spiking water solutions with $10 \mu \mathrm{L}$ of $10 \mathrm{~nL} / \mathrm{mL}$ standard solution of EPA 8081A was initially used. White tests were used regularly during the analysis of water samples and also recovered $(82.7 \pm 12.6 \%)$, reproducibility $(96.4 \pm 7.3 \%)$, repeatability $(92.8 \pm 13.5 \%)$, LOD $(0.03-0.05 \mathrm{ng} / \mathrm{ml})$, LOQ $(0.1-0.15 \mathrm{ng} / \mathrm{ml})$ of the method used for each of the organochlorinated pesticides. 


\section{- GC/FID Method for PAH determination}

Preparation of water samples for PAH analyzes: PAH in water samples was extracted using liquid-liquid extraction assisted with a $\mathrm{n}$ - hexane solvent. 1L of water and $40 \mathrm{ml}$-hexane as the extract solvent was added in a separatory funnel. After shaking, the organic phase was collected in a beaker where $10 \mathrm{~g}$ of anhydrous Na2SO4 was added for removing water. The solvent was evaporated using Kuderna-Danish up to $2 \mathrm{ml}$ and injected into the Varian 450 gas chromatograph apparatus equipped with a FID detector.

A VF-1 ms capillary column $(30 \mathrm{~m} \times 0.33 \mathrm{~mm} \times 0.25 \mu \mathrm{m})$ was used to isolate and determine PAH compounds in separate injections. The temperature for FID was held at $280^{\circ} \mathrm{C}$. Nitrogen was used as a carrier and make-up gas for both analyses. Hydrogen and air were flame detector gases with $30 \mathrm{ml} / \mathrm{min}$ and $300 \mathrm{ml} / \mathrm{min}$, respectively. The quantification of PAH was based on the EPA 525 standard, using an external standard method.

Calibration curves for 13 PAHs according to EPA 525 were constructed with five calibration points using solutions with concentrations of $12.5 \mu \mathrm{g} / \mathrm{ml}, 25 \mu \mathrm{g} / \mathrm{mL}, 50 \mu \mathrm{g} / \mathrm{ml}, 100 \mu \mathrm{g} / \mathrm{ml}$ and $250 \mu \mathrm{g} / \mathrm{ml}$. A set of bi-distilled spiking water solutions with $10 \mu \mathrm{l}$ of $12.5 \mu \mathrm{l} / \mathrm{ml}$ standard solution of EPA 525 was initially used to evaluate the working method. White tests were regularly used during the analysis of water samples and also calculated recovery $(78.1 \pm 21.5 \%)$, reproducibility $(90.5 \pm 11.3 \%)$, repeatability $(85.4 \pm 18.9 \%)$, LOD $(0.3-0.5 \mu \mathrm{g} / \mu \mathrm{l})$, LOQ $(1.0-1.5 \mu \mathrm{g} / \mathrm{ml})$ and methods used for each of PAH.

\section{Results and Discussions}

The analysis of organic pollutants in water samples on the Seman Basin was conducted during the April - May 2019 period, in two expeditions at 6 sampling stations. Chlorinated organic pollutants pesticides (OPC), their residues and PCBs were determined by the GC/ECD technique. PAHs were determined by a capillary column with the GC/FID technique. OCPs, PCBs and PAHs were extracted using liquid-liquid extraction.

Figure 2 shows the total of organochlorine pesticides in water samples of Seman Basin analyzed in April May, 2019.

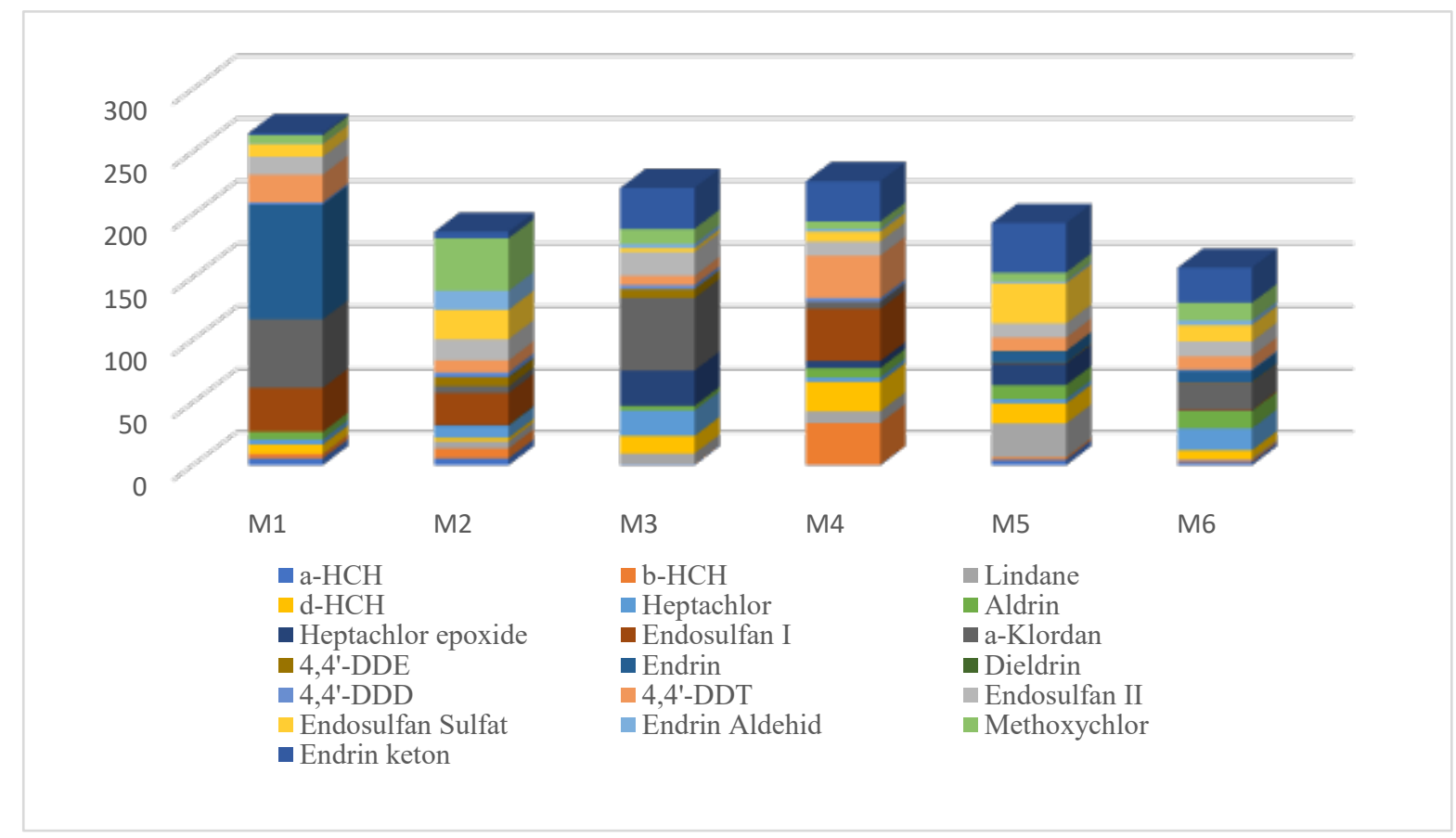

Fig 2. Total of organochlorine pesticides (ng/L) in water samples of Seman Basin April - May, 2019

The organochlorine pesticides detected were HCB, HCHs (alpha-, beta-, gama- and delta-isomers) and the DDTrelated chemicals (p,p-DDE, p,p-DDD, p,p-DDT), Aldrines (Aldrine, Dieldrine, Endrine) and Heptachlors. Referring to the 
total concentration values of OPC, it is visible that the lowest value for the total concentration of this class is $164.25 \mathrm{ng} / \mathrm{lin}$ station M6, and the highest level of these pollutants was found in the samples taken at station M1, with a total value of $270.645 \mathrm{ng} / \mathrm{l}$. The highest value of the OPC concentration for Endrine is $91.49 \mathrm{ng} / \mathrm{l}$ in the water samples of station M1.

Figure 3 shows the profile of organochlorine pesticides in water samples of the Seman Basin

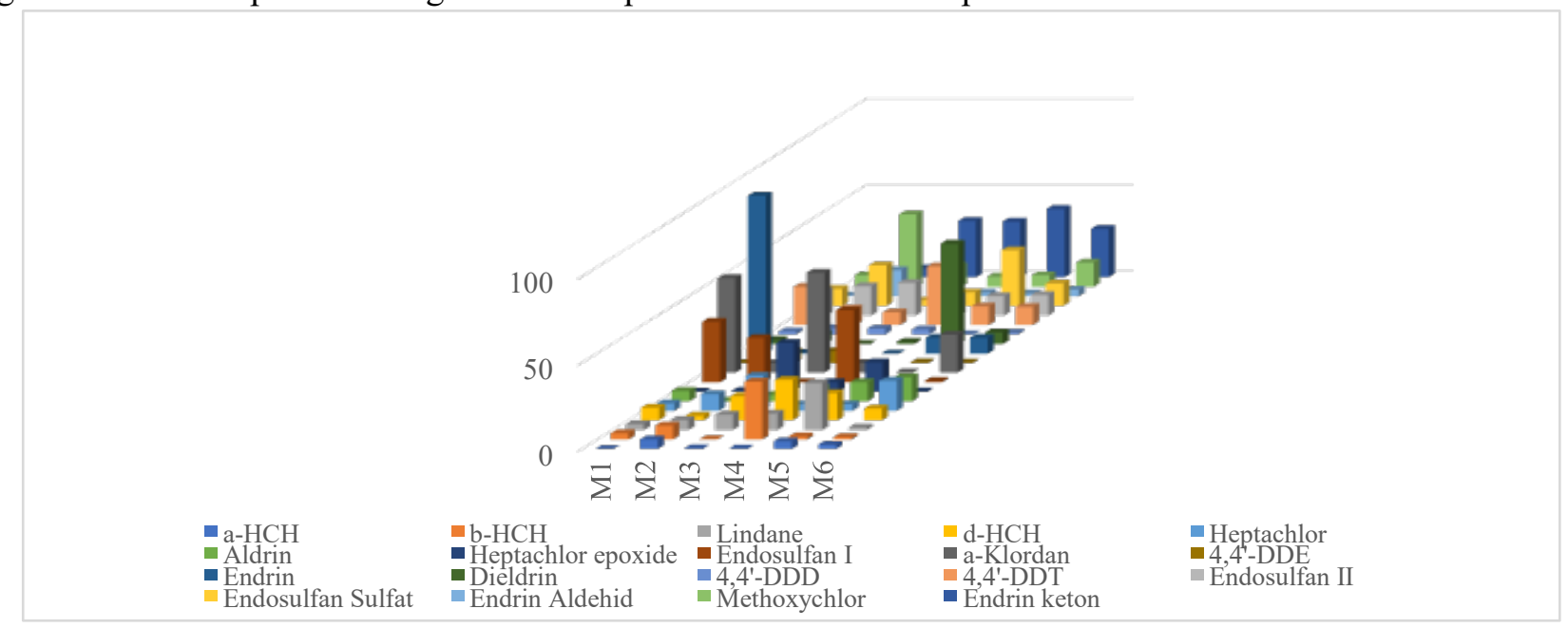

Fig 3. Profile of organochlorine pesticides (ng/L) in water samples of Seman Basin, April - May 2019

The presence of almost all OPCs taken in the study is noticed. The profile of organochlorine pesticides in the Seman Basen was: Endrine $>$ Endosulfan I $>4,4^{\prime}$-DDT $>$ Endosulphane Sulphate $>$ Endosulphan II $>$ Dieldrine $>$ d-HCH $>$ Lindane $>\mathrm{b}-\mathrm{HCH}$. This profile of pesticides is associated with their previous uses in agricultural areas near the upper-stream and lower-stream of the Seman basin.

In all water samples taken for analysis the levels of organochlorine pesticides do not exceed the levels allowed under EU Directive 98/83 / EC [3]. (the allowed value of pesticides is 100ng/L).

The total of PCB (ng/L) values in the water samples of the Seman basin, is shown in Figure 4.

700

600

500

400

300

200

100

0
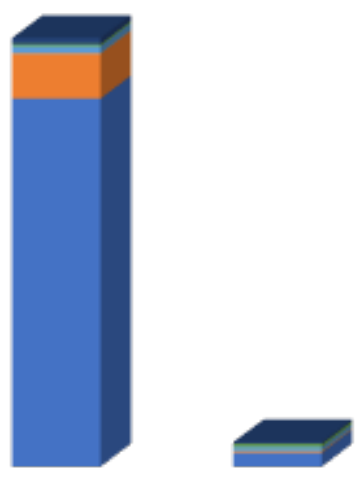

M1

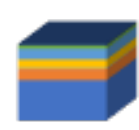

$\mathrm{M} 2$
$\mathrm{M} 3$

PCB 28

$\square$ PCB $52 \square$ PCB 101

\begin{abstract}
M4
\end{abstract}

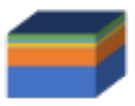

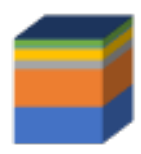

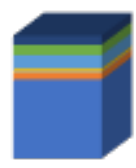

M5

M6

Fig 4. Total of PCB (ng/L) values in water samples of the Seman Basin, April - May 2019 
What is noticed is that these pollutants were found in almost all samples analyzed. The Seman and Gjanica river levels, as well as different discharges, are important factors which have an impact on the levels and the types of these pollutants in the river.

Figure 5 shows the profile of PCBs in the water samples of the Seman basin.

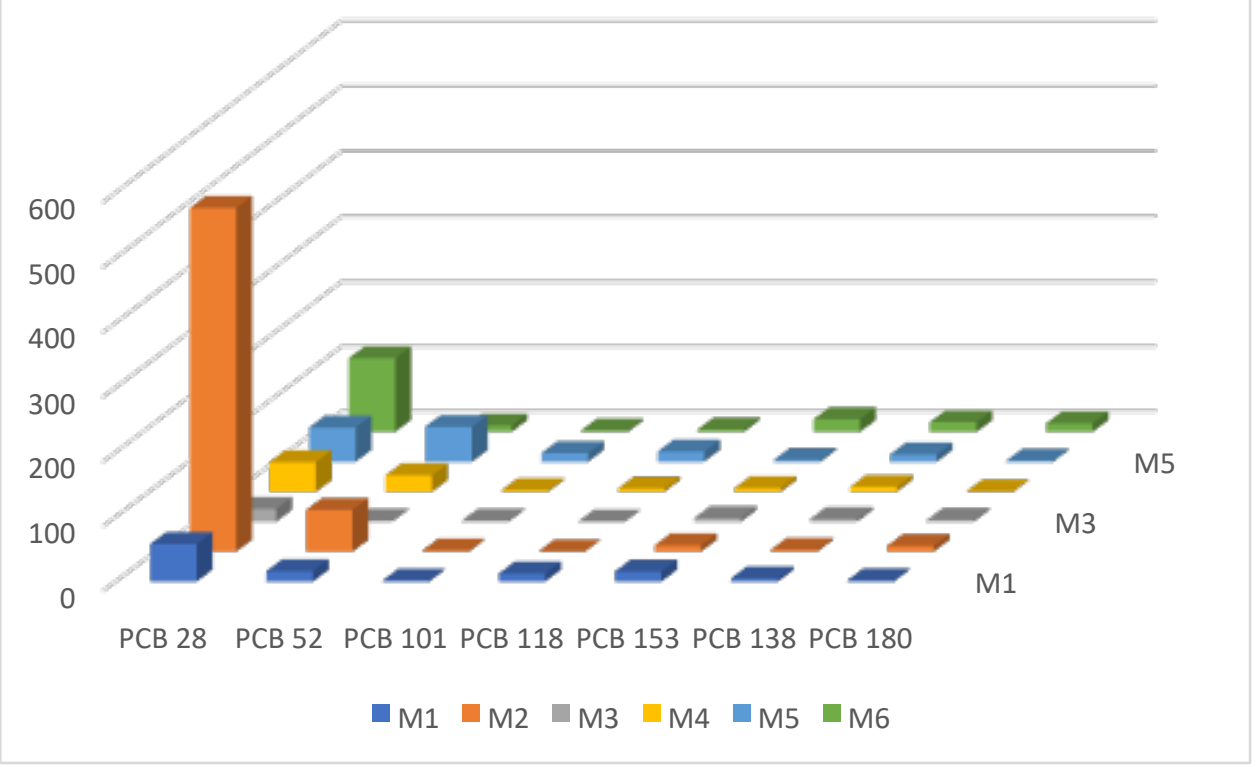

Fig 5. Profile of PCB (ng/L) in water samples of Seman Basin, April - May 2019

The profile is built from PCB28> PCB52> PCB153> PCB138> PCB118> PCB180> PCB101. High PCB 28 values are observed at station M2. PCB 28 was found to be more abundant than other PCBs in all samples studied. Also, PCB 52 and PCB 153 with significant values were detected, the origin of which may be from point sources from lands near the river. This is mainly related to uncontrolled wastewater discharges into the Seman basin.

Compared to international standards (98/83 / EU Directives) [3] we can say that the studied waters, with the exception of those of station M2, fulfill these standards by classifying them as waters of good environmental quality.

Figure 6 , shows the total concentrations of PAHs $(\mu \mathrm{g} / \mathrm{L})$ in the water samples of the Seman basin.

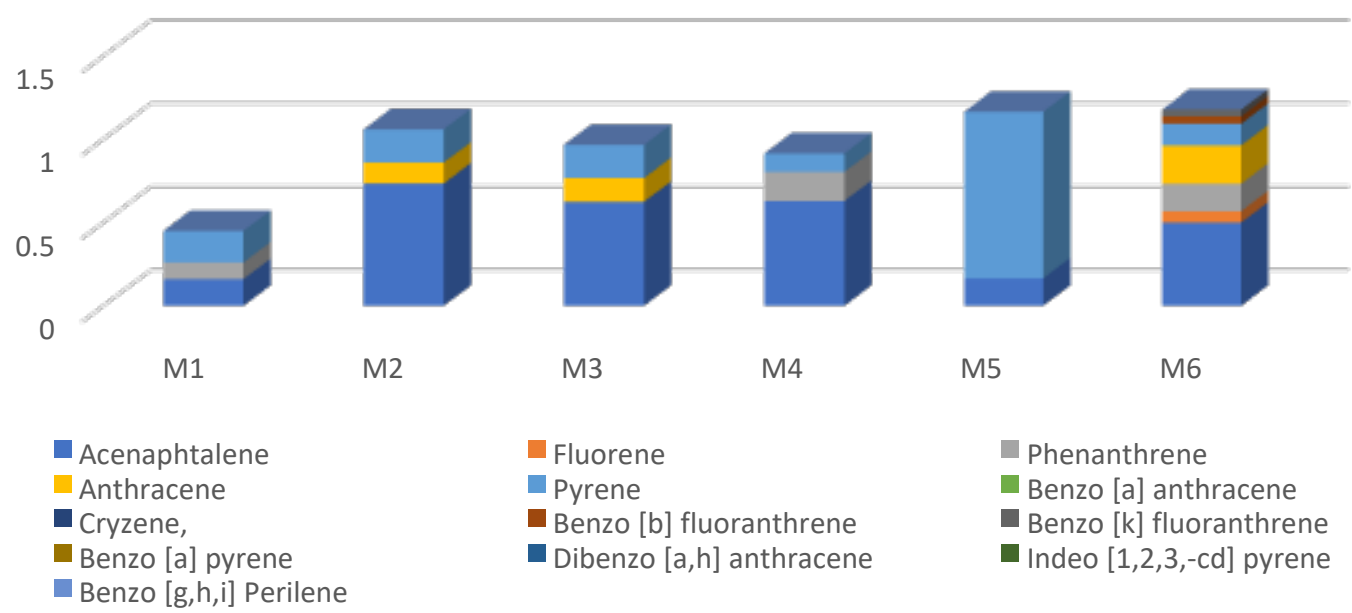

Fig 6. Total of PAH $(\mu \mathrm{g} / \mathrm{L})$ in the water samples of Seman Basin, April - May 2019 
In all the samples the presence of PAH was detected. The highest level of total PAH content was detected in the M6 station samples $(1.178 \mu \mathrm{g} / \mathrm{L})$ and the lowest values of concentrations were in the water samples of the M1 station $(0.45 \mu \mathrm{g} /$ L). The profile of PAH individuals is shown in Figure 7.

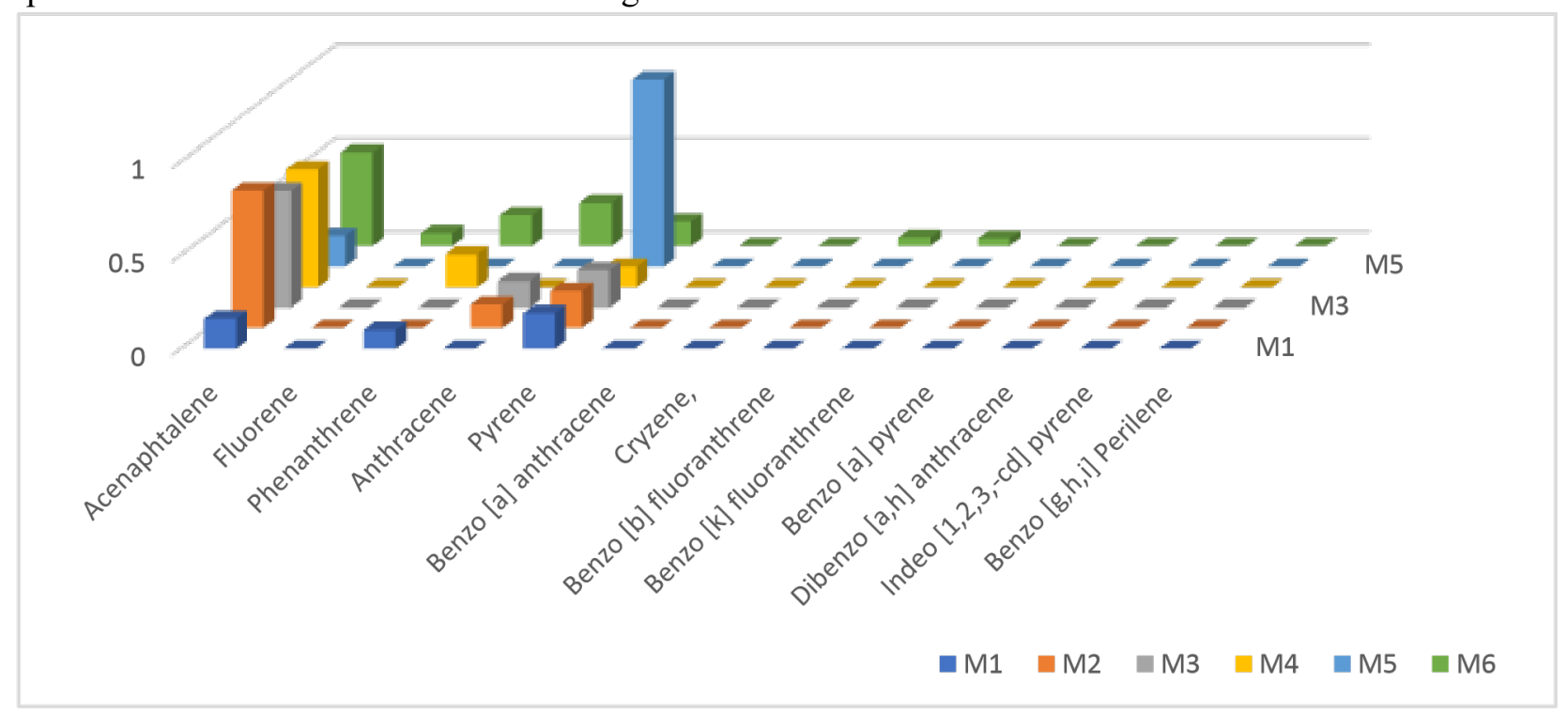

Fig 7. Profile of PAH $(\mu \mathrm{g} / \mathrm{L})$ in water samples of the Seman Basin, April - May2019

This profile is constructed as follows:

Acenaphthalene $>$ Pyrene $>$ Anthracene $>$ Phenanthrene $>$ Fluorene $>$ Benzo [b] Fluorantrene $>$ Benzo $[\mathrm{k}]$

Fluorantrenine. Other PAHs were not detected in any water samples of the stations taken in the study. PAH levels and their profile in the waters of the Seman basin can be explained by the discharges of industrial waters in one of its branches, Gjanica, which collects all industrial waters of the district of Fier and the Ballsh area, an area in which also has the largest concentration of oil wells.

However, it is worth noting that in all samples taken in the analysis the PAH levels do not exceed the levels allowed under EU Directive 98/83 / EC.

\section{Conclusions}

\section{The below conclusions were drawn from this study:}

- The presence of almost all organochlorine pesticides (OPC) was detected in the surface waters of the Seman basin. In all water samples taken for analysis the levels of organochlorine pesticides do not exceed the levels allowed under EU Directive 98/83 / EC. (the allowed value of pesticides is 100ng / L).

- Marker PCBs were found in almost all samples analyzed, but are under the allowed level of EU norms or under the method detection limits therefore are not a current pollution concern, with the exception of those of station M2. Areas with the highest concentration of PCBs are the ones closest to inhabited centers with developed agricultural activity. (such as station M2 of the Hoxhara channel which pours into the Adriatic Sea on the beach of Seman) This channel also brings all the discharge of the Ballsh oil industry making it a very polluted channel. The Seman and Gjanica river levels, as well as different discharges, are important factors which have an impact on the levels and the types of pollutants in the river.

- PAH levels and profile in the waters of the Seman basin can be explained by the discharges of industrial waters in one of its branches, Gjanica, which collects all industrial waters of the district of Fier and the Ballsh area, an area in which also has the largest concentration of oil wells. However, it is worth noting that in all samples taken in the analysis the PAH levels do not exceed the levels allowed under EU Directive 98/83 / EC. 


\section{From this study we recommend:}

- Continuous control of the environmental condition of the studied waters to have further details on the condition of this river basin.

- Creating a database of different discharges along the basin.

- Taking legal measures via local government bodies to minimize the causes of pollutants by controlling the usage of prohibited organic pollutants.

- Increasing the awareness of citizens about the protection of the aquatic environment and informing them about the health risks of organic pollutants to humans.

\section{References}

[1] Pine.O. Analysis of organic pollutants in food products by gas chromatography techniques, Ph.D. dissertation, Faculty of Natural Sciences, TU (2017).

[2] Tahiraj.J. Assessment of the environmental condition of the Elbasan area by determining the levels of organic and inorganic pollutants with instrumental methods. Ph.D. dissertation, Faculty of Natural Sciences, TU (2019)

[3] Council Directive 98/83/EC (1998): On the quality of water intended for human consumption.Annex I. Official Journal of the European Union

[4] D. Erickson Introduction: PCB properties, uses, occurrence, and regulatory history. In: Robertson, Hansen L.W., Edison L.G., PCBs: Recent Advances in Environmental Toxicology and Health Effects. The University Press of Kentucky, Lexington, Kentucky, pp. 131-152. (2001)

[5] Hoxha M, Zoga P, Bode A, Xhulaj S, Memushaj L): Overview of water pollution in the Seman watershed, Scientific Bulletin, Ismail Qemali University, No. 1, vol 2, pg 147 - 151. (2013) [6] Longnecker MP, Klebanoff MA, Zhou H and Brock JW Association between maternal serum concentration of the DDT metabolite DDE and preterm and smallfor- gestational-age babies at birth. Lancet 358(9276). pp.110-114(2001)

[7] MAP No.7, rev. 2, 1984 dhe UNEP/MED Wg.128/2, (1997)

[8] Porta M., Malats N., Jariod M., Grimalt JO., Rifà.J. and Carrato A.,.Serum concentrations of compounds and K-ras mutations in exocrine pancreatic cancer. PANKRAS II Study

Group. Lancet 354(9196): 2125-2129(1999)

[9] S. Safe. Polychlorinated biphenyls (PCBs): environmental impact, biochemical and toxic responses, and implications for risk assessment. Criteria Revisit of Toxicology 24(2):87-149. (1994)

[10] Sharawi M.S., Hamza A., Bashammakh A.S. and Al-Saggaf W.T. An overview on the accumulation, distribution, transformations, toxicity and analytical methods for the monitoring of persistent organic pollutants, Talanta, 80 , pp. 1587 - 1597. (2010).

[11] Ribas-FitóN., Sala M., Cardo E., Mazón C., Muga MED. and Verdú A.Association of hexachlorobenzene and other organochlorine compounds with anthropometric measures at birth. $\quad$ Pediatr Res 52(2): 163-167 (2002). 